\title{
THE COMPLETE MITOCHONDRIAL GENOMES OF FOUR ENDEMIC BAIKAL MOLLUSKS (MOLLUSCA: CAENOGASTROPODA)
}

\author{
T.E. Peretolchina, T.Ya. Sitnikova, D.Yu. Sherbakov \\ Limnological Institute SB RAS, Irkutsk, e-mail: tatiana.peretolchina@gmail.com
}

Mollusks are one of the important components of Baikal fauna. There are more than 180 species of mollusks in the lake and 41 of them belong to the endemic subfamily Baicaliinae Fisher, 1885, which is considered as a subfamily of the big family Amnicolidae Tyron, 1863 by molecular data (Wilke et al. 2013). Here we present the complete mitochondrial (mt) genomes of four snails belonging to the different genus of Baicaliinae. These mollusks inhabit littoral zone of Lake Baikal and mainly differ by ecological behavior and substrate preferences: Korotnewia korotnewii and Godlewskia godlewskia are mobile detritophages and inhabit sandy bottoms, while Baicalia turriformis and Maackia herderiana are sestonophages and prefer rocks surfaces. The result provides fundamental data for resolving phylogenetic relationships and evolution problems.

Mollusks were collected by scuba divers in southeastern (Murinskaya banka, $51^{\circ} 29^{\prime} 13.00^{\prime \prime} \mathrm{N} 104^{\circ} 19^{\prime} 3.20 " \mathrm{E}$ ) and southwestern (Varnachka bay, 51 53'54.27"N 105 7'10.74"E) littoral of Lake Baikal at depths of 10 to 20 meters in August - September of 2015. Typically they were brought live into the laboratory, but some samples were fixed in $80 \%$ ethanol in the field. Genomic DNA was extracted by modified method of Sokolov (2000) from the muscle tissue. Sequencing was performed by "GENOTEK" (Moscow) using Illumina HiSeq2000 system with read length 100PE (Illumina, San Diego, CA). The quality trimming and removing of adapters from reads was made by Trimmomatic-0.32 (Bolger et al., 2014). Processed reads were assembled de novo with MIRA 4 (Chevreux, 1999) using MITObim 1.8 (Hahn et al 2013). The mitochondrial genome of Potamopyrgus estuarinus (Neiman et al 2010) was used to identify mitochondrial scaffolds of K. korotnewii, G. godlewskia, $B$. turriformis and $M$. herderiana in the assembly using BLAST. The mitochondrial DNA sequences were annotated using MITOS pipeline (Bernt et al., 2013). Resulting gene boundaries were determined by alignment with homologous regions of published mitochondrial genomes (mitogenomes) of gastropods and by findings the ORFs employing the invertebrate mitochondrial genetic code. Nucleotide composition of mitogenome sequences was calculated using Mega 6 (Tamura et al., 2013).

All mt genome sequences were deposited in GenBank (KY697386 - KY697389). Their total length ranges from 15,127 bp (B. turriformis) to 15,224 bp (G. godlewskia) and coincides with average caenogastropod mitogenomes sequenced $(11.1-16.7 \mathrm{Kbp})$ (Wang et al., 2017). Their A+T content vary non-significantly from $66.5 \%$ (G. godlewskia) to $67.5 \%$ (B. turriformis).

All mitochondrial genomes sequenced, like most metazoan mt genomes, contain 13 protein-coding genes, two ribosomal RNA genes (L-rRNA and S-rRNA), 22 transfer RNA genes. Most of genes are encoded on the heavy strand $(+)$, and only eight tRNA genes (Met, Tyr, Cys, Trp, Gln, Gly, Glu, Thr) on the light strand (-) that is typical for Caenogastropoda. Twenty two tRNA genes vary from 62 to 79 bp in length. Among 13 protein-coding genes, the maximum is ND5 with $1717 \mathrm{bp}$ and the minimum is ATP8 with only $159 \mathrm{bp}$. S-rRNA and L-rRNA genes are 861-864 and 1374-1383 bp located between the tRNA ${ }^{\text {Glu }}$ and tRNA ${ }^{\text {Leu }}$ genes and separated by the $\mathrm{tRNA}^{\mathrm{Val}}$ gene. The most common initiation codon was predicted to be ATG. Initiation codon ATA was observed only one time (ND4 gene) in B. turriformis and $M$. herderiana species. Stop codons were either TAA or TAG (one - three times in different species of Baicalia). The absence of D loop is also typical for the Gastropoda (Liu et al. 2012; Zeng et al. 2015; Zhou et al. 2016). 
Gene arrangement and distribution of Baikal mollusks mitogenomes studied are similar to the most of Caenogastropoda (Wang et al. 2017; Yang et al 2016; Simison et al 2006; Bandyopadhyay et al 2006). The majority of all living sea and freshwater gastropods are classified within the Caenogastropoda (Mollusca: Gastropoda) clade, which comprises approximately 136 extant families of snails (Colgan et al., 2007). Among all mitogenomes of Caenogastropoda sequenced and available in GeneBank, majority of them exhibited highly conserved gene order with minor discrepancies connected with the position of some tRNAs, and among of representatives of two superfamilies only (Vermetoidea and Cerithioidea) gene arrangement was different (Wang et al., 2017). Caenogastropoda is supposed retain ancestral gene arrangement (Grande et al., 2008).

Results of the analysis of mitogenome sequences of these mollusks can be used for further study of the scenarios of speciation and evolution of the Baikal mollusks fauna.

\section{References}

Bernt M., Donath A., Ju“hling F., Externbrink F., Florentz C., Fritzsch G., Putz J., et al. MITOS: Improved de novo metazoan mitochondrial genome annotation // Molecular Phylogenetics and Evolution. - 2013. - V. 69. - P. 313-19.

Bolger AM, Lohse M, Usadel B. Trimmomatic: A flexible trimmer for Illumina sequence data. // Bioinformatics. - 2014. - V. 30. - P. 2114-20.

Chevreux B., Wetter T. and Suhai S. Genome Sequence Assembly Using Trace Signals and Additional Sequence Information. // Computer Science and Biology: Proceedings of the German Conference on Bioinformatics (GCB). - 1999. - V. 99. - P. 45-56.

Colgan D.J., Ponder W.F., Beacham E., Macaranas J. Molecular phylogenetics of Caenogastropoda (Gastropoda: Mollusca). // Molecular Phylogenetics and Evolution. - 2007. - V. 42 (3). P. 717-37.

Grande C., Templado J., Zardoya R. Evolution of gastropod mitochondrial genome arrangements. // BMC Evolutionary Biology. - 2008. - V. 8, №. 1. - P. 61.

Hahn C, Bachmann L, Chevreux B. Reconstructing mitochondrial genomes directly from genomic next-generation sequencing reads--a baiting and iterative mapping approach // Nucleic Acid Research. - 2013. - V. 41. - 13: e129.

Liu G.H., Wang S.Y., Huang W.Y., Zhao G.H., Wei S.J., Song H.Q., Xu M.J., Lin R.Q., Zhou D.H., Zhu X.Q. The complete mitochondrial genome of Galba pervia (Gastropoda: Mollusca), an intermediate host snail of Fasciola spp. // PLoS One. - 2012. - 7:e42172.

Simison W.B., Lindberg D.R., Boore J.L.: Rolling circle amplification of metazoan mitochondrial genomes. // Molecular Phylogenetics and Evolution. - 2006. - V. 39. - P. 562-567.

Sokolov E.P. An improved method for DNA isolation from mucopolysacchride-rich molluscan tissues. // Journal of Molluscan Studies. - 2000. - V. 66. - P. 573-575.

Tamura K., Stecher G., Peterson D., Filipski A., Kumar S. MEGA6: Molecular evolutionary genetics analysis, Version 6.0. // Molecular Biology and Evolution. - 2013. - V. 30. - P. 2725-2729. (doi: 10.1093/molbev/mst197).

Wang J.G., Zhang D., Jakovlić I., Wang W.M. Sequencing of the complete mitochondrial genomes of eight freshwater snail species exposes pervasive paraphyly within the Viviparidae family (Caenogastropoda) //PloS one. - 2017. - V. 12, № 7. - P. e0181699.

Wilke T., Haase M., Hershler R., Liu H.-P., Misof B., Ponder W. Pushing short DNA fragments to the lomit: 'hydrobioid' gastropods (Caenogastropoda: Rissoidea) // Molecular Phylogenetics and Evolution. - 2013. - V. 66. - P. 715-736. doi: 10.1016/j.ympev.2012.10.025.

Yang H., Zhang J. E., Deng Z., Luo H., Guo J., He S., ... \& Zhao, B. The complete mitochondrial genome of the golden apple snail Pomacea canaliculata (Gastropoda: Ampullariidae) // Mitochondrial DNA Part B. - 2016. - V. 1, № 1. - P. 45-47.

Zeng T, Yin W, Xia R, Fu C, Jin B. Complete mitochondrial genome of a freshwater snail, Semisulcospira libertina (Cerithioidea: Semisulcospiridae). // Mitochondrial DNA. - 2015. - V. 26, № 6. P. 897-8.

Zhou X., Chen Y., Zhu S., Xu H., Liu Y., Chen L. The complete mitochondrial genome of Pomacea canaliculata (Gastropoda: Ampullariidae) // Mitochondrial DNA. - 2016. - V. 27, № 2. P. 884-5. 